\title{
Democracia e Saúde: Sociedade Civil, Cidadania e Cultura Política
}

A realização da XII Conferência Nacional de Saúde foi um momento oportuno de reflexão e discussão sobre as lacunas e desafios a serem enfrentados e as diretrizes propostas para o avanço na consolidação do SUS e da Reforma Sanitária brasileira, particularmente nos próximos quatro anos. Mais do que isso, entendemos que as conferências de saúde devam constituir espaços públicos de efetiva participação política da sociedade civil, contribuindo para a democratização das ações do Estado na construção do direito à saúde no Brasil contemporâneo. Contudo, as práticas de participação da sociedade civil brasileira nos espaços públicos têm evidenciado que o processo de construção democrática não é linear, mas contraditório e fragmentado.

Vários fatores estão vinculados a esse processo. Entretanto estes não incluem, na maioria das vezes, a possibilidade de conceder à sociedade civil o papel de protagonista do aprofundamento democrático, no que concerne à formulação, implantação e execução das políticas públicas no país. Em que pese o pioneirismo da área da

saúde na democratização das relações entre Estado e sociedade civil, mediante a criação de instâncias políticas de participação e controle social nas três esferas de governo - os conselhos -, é possível verificar no cotidiano das instituições a predominância de uma cultura política conservadora, patrimonialista e autoritária. Nesta, o Estado desempenha papel central, estando sempre inclinado a limitar a participação e a representatividade da sociedade civil aos tradicionais mecanismos de institucionalidade democrática: os partidos políticos e eleições governamentais.

Essa constatação é corroborada pela habitual definição de Estado como um conjunto de forças que ocupa o poder em vários níveis (municipal, estadual 
e federal). No entanto, sua estrutura é estatal, e seu desenho autoritário continua intocado e resistente aos impulsos democráticos. Podemos perceber, ao longo da história das Conferências Nacionais de Saúde, o surgimento de um conjunto crescente de demandas por saúde, fruto de movimentos sociais organizados que reivindicam a inclusão, na agenda política, de novas prioridades, cada vez mais específicas e complexas.

Um dos efeitos dessa inclusão é a recorrente reivindicação de mais espaços públicos de participação da sociedade civil na tomada de decisão e controle sobre as políticas de saúde, forjando diferentes rearranjos institucionais de vocalização das demandas por saúde, tais como colegiado de gestão, fóruns e ouvidorias públicas. Com isso, torna-se cada vez mais evidente a necessidade de convivência entre práticas fundadas na democracia participativa e na democracia representativa, como nexo constituinte de garantia dos direitos de cidadania, o que exige maior porosidade das instituições aos valores democráticos inerentes ao processo de consolidação da saúde como direito e como serviço.

Nesse sentido, o direito à saúde, como um direito de cidadania, assume caráter de estratégia política, que se baseia numa abordagem afirmativa dos problemas demandados pela população, com participação da sociedade civil. Os efeitos dessa abordagem têm sido o surgimento de respostas governamentais caracterizadas por práticas que associam o exercício da democracia à participação política em diferentes espaços públicos, estatais ou não, a institucionalização do controle social na fiscalização das ações do Estado e a garantia de acesso a bens e serviços de saúde.

Essas práticas surgem do movimento de luta de uma sociedade civil que não se configura como um pólo oposto do Estado. Sociedade civil é entendida aqui no sentido gramsciano do termo, que a define uma arena privilegiada de luta, uma esfera do ser social onde se dá uma intensa luta pela hegemonia. Exatamente por isso, ela não pode ser "outro" do Estado, mas, junto com a sociedade política, é um dos elementos constitutivos de suas ações. O par conceitual sociedade civil / Estado deve ser concebido como uma unidade na diversidade e, portanto, não é possível alimentar uma dicotomia radical por uma ênfase maniqueísta de que o Estado é tudo de ruim e a sociedade civil é tudo de bom, ou vice-versa. 
Dessa maneira propomos aqui, em síntese, a idéia de pensar as relações sobre a democracia e a saúde, a partir da análise crítica das práticas de participação e controle social da sociedade civil em diferentes espaços públicos das políticas de saúde, entendendo que seu efetivo exercício possa configurar novos arranjos institucionais, capazes de repercutir na cultura política do país e ajudar na construção de políticas mais justas e solidárias.

Como contribuição para essa discussão, quatro artigos deste número de Physis abordam o tema da democracia e saúde, a partir de uma leitura crítica das diferentes formas de participação da sociedade civil nas políticas públicas em saúde em distintos planos de sua concretização, ou seja, nos planos macro, micro e molecular das relações entre sujeitos no cotidiano das instituições. No primeiro artigo, Francini Guizardi e colaboradores apresentam os resultados parciais de um estudo exploratório que se destina a analisar a trajetória da participação da comunidade. Resulta do processo social das Conferências Nacionais de Saúde, a partir do mapeamento dos discursos e argumentos dos sujeitos, no qual se destaca a necessidade de rediscutir os espaços institucionais de participação existentes, sobretudo as maneiras de "formulá-las" e "organizá-las", na medida em que confere relações de poder tão assimétricas, capazes de negar as possibilidades de autoria da comunidade na efetivação do SUS e de seus princípios, e da democratização das relações entre Estado e sociedade.

Ricardo Ceccim e Laura Feuerwerker, no artigo seguinte, trazem uma abordagem teórica inovadora sobre a educação e seus efeitos no setor saúde, a partir da experiência institucional em curso, que identifica quatro elementos intercessores de novas práticas para a formação profissional: ensino, gestão, atenção e controle social. Estes são capazes de esposar diferentes movimentos de construção e organização de uma gestão de educação na saúde, reconfigurando a imagem dos serviços como gestão e atenção em saúde e valorizando o controle social.

$\mathrm{Na}$ seqüência, Eymard Vasconcelos apresenta uma discussão sobre novos desenhos políticos e institucionais de disseminação e apreensão dos saberes ditos populares, que qualificam a Educação Popular com atributos capazes de fomentar resoluções concretas às demandas apresentadas pela população. O processo se dá a partir de abordagens participativas, enaltecedoras 
de um saber-fazer coletivo e solidário, e deve ser concebido como uma estratégia contra-hegemônica de um modelo biologizante e de efetivação do SUS.

Por último, Alcindo Ferla, com base num estudo cartográfico, identifica nexos constituintes entre as práticas de participação e controle social da sociedade civil em espaços públicos e estatais em saúde e as possibilidades de reconfiguração da clínica e da gestão. Propõe uma nova estética dos conceitos que os definem, denunciando a insuficiência de recursos teóricos da ciência moderna em apreender o poder do controle social para transformar e emancipar os sujeitos na produção do cuidado em saúde. 